\title{
The effect of the design and material parameters on the temperature gradient in lightweight valves in the valvetrains of combustion engines
}

\begin{abstract}
According to the current trend to reduce the valvetrain movable masses in combustion engines lightweight valves are used increasingly. They can be made of light alloys from the TiAl alloy group or of ceramic materials such as silicon nitride. They are often coated with additional protective layers to reduce the resistance of friction or the wear intensity. They may also be a hollow structure made of steel with internal reinforcing ribs. Compared to traditional full steel valves they are characterized by different temperature gradients when working in a valvetrain. As a result, their working change, particularly the intensity of the heat transfer and wear. The paper presents valve models developed with the FEM technique for several design and material configurations for lightweight intake and exhaust valves operating under conditions similar to those made of steel. Also the temperature gradients of the discussed valves have been included and compared to those of full steel valves.
\end{abstract}

Key words: combustion engine, valvetrain, lightweight valve, temperature gradient

\section{Wpływ parametrów konstrukcyjnych i materiałowych na rozkład temperatury w lekkich zaworach rozrządu silników spalinowych}

\begin{abstract}
Streszczenie: Zgodnie z obecna tendencją do zmniejszania mas ruchomych rozrzadu w silnikach spalinowych stosowane sa lekkie zawory. Moga być one wykonane z lekkich stopów z grupy TiAl lub z materiatów ceramicznych jak azotek krzemu. Często sa powlekane dodatkowymi warstwami ochronnymi dla zmniejszenia oporów tarcia lub intensywności zużycia. Moga to być też zawory stalowe drą̇̇ne, z ewentualnym zastosowaniem wewnetrznych żeber wzmacniajacych. W stosunku do klasycznych petnych zaworów stalowych odznaczają sie one innym rozkładem temperatury podczas pracy w rozrzadach. W efekcie zmieniają się ich warunki pracy, a zwłaszcza intensywność odbioru ciepła i zużywania. W artykule przedstawiono opracowane modele zaworu, wykonane przy użyciu MES, dla kilku konfiguracji konstrukcyjnych i materiałowych lekkich zaworów dolotowych $i$ wylotowych, pracujacych $w$ zbliżonych warunkach jak petne zawory stalowe. Zamieszczono tez obliczone rozkłady temperatury i porównano je z przypadkiem petnych zaworów stalowych.
\end{abstract}

Słowa kluczowe: silnik spalinowy, rozrząd silnika, lekki zawór, rozkład temperatury

\section{Introduction}

According to current trends aiming at a reduction of the movable masses in engine valvetrains lightweight valves are used increasingly in internal combustion engines. They can be made of light alloys of the TiAl group or ceramic materials such as silicon nitride. They are often coated with additional protective layers to reduce friction or wear intensity. They may also be a hollow structure made of steel with internal reinforcing ribs. Compared to classic full steel valves they are characterized by a different temperature gradient during operation in a valvetrain. As a result, their working conditions are variable, particularly the intensity of the heat transfer and wear. The aim of the present work is to calculate the temperature gradients in a lightweight valve for its several different design and material configurations and to compare such gradients to the gradients of a full steel valve of similar geometry.

\section{Methods to reduce weight of valves in a valvetrain}

In all valvetrain configurations, the reduction of movable masses, including valves, is a preferred solution. In fact, this results in a decrease in the motion resistance, the force required for the valvetrain drive and the fuel

\section{Wprowadzenie}

Zgodnie z obecną tendencją do zmniejszania mas ruchomych rozrządu w silnikach spalinowych stosowane są lekkie zawory. Mogą być one wykonane z lekkich stopów z grupy TiAl lub z materiałów ceramicznych jak azotek krzemu. Często są powlekane dodatkowymi warstwami ochronnymi dla zmniejszenia oporów tarcia lub intensywności zużycia. Mogą to być też zawory stalowe drążone, $\mathrm{z}$ ewentualnym zastosowaniem wewnętrznych żeber wzmacniających. W stosunku do klasycznych pełnych zaworów stalowych odznaczają się one innym rozkładem temperatury podczas pracy w rozrządach. W efekcie zmieniają się ich warunki pracy, a zwłaszcza intensywność odbioru ciepła i zużywania. Celem obecnej pracy jest obliczenie rozkładów temperatury w lekkim zaworze, dla jego kilku różnych konfiguracji konstrukcyjnych i materiałowych oraz porównanie tych rozkładów z występującymi w pełnym zaworze stalowym o zbliżonej geometrii.

\section{Sposoby zmniejszania masy zaworów rozrządu}

We wszystkich konfiguracjach rozrządu zmniejszenie mas ruchomych, w tym zaworów jest korzystne. Skutkuje to bowiem zmniejszeniem oporów ruchu, wymaganej mocy napędu rozrządu i zużycia paliwa. Silnik może pracować 
consumption. The engine can operate faster, transfer more of the load and be more efficient. Valves with a reduced diameter of their stems are very often used, which results in a reduction of their weight by $8-10 \%$ compared to standard valves. Using lighter valves reduces the stress in the springs, cups, rockers, tappets and timing cams. A weight reduction of the intake valves is more effective than that of the exhaust ones for obtaining higher engine speeds. Because of larger diameters of their heads, intake valves are heavier than the exhaust ones. Further valve weight reduction can be achieved by drilling them and/or manufacturing them from lightweight materials. The use of light valve allows an application of weaker springs of lower weight. The product of the negative acceleration and of the sum of the valve mass and the partial mass of the spring allows estimating the spring force. Weight reduction of the valve by $40 \%$ allows a reduction in the spring stiffness by approximately $30 \%$ [1].

To conclude, lightweight valves may come as hollow, made of steel, TiAl alloy or ceramic.

\section{Drilled valves}

As has been mentioned above, one way to reduce the valve weight is the use of their drilled version. Valve stems are drilled and micro-polished. Such drilling can be performed at $2 / 3$ of the upper part of the stem where the stiffness is one order of magnitude lower than in the zone just above the valve head. After drilling a hardened tip is welded at the top of the stem. As a result we obtain a valve lighter up to $20 \%$. The use of drilled valves replacing the traditional ones can increase the engine speed range of 300-350 rpm without the need to modify the valvetrain [2].

Micropolishing reduces the risk of the occurrence of indentations on the inner surface of the stem [3].

Drilling reduces the strength; hence the valves must be built from stronger alloys. The durability of drilled valves used in naturally aspirated engines is comparable to that of the undrilled ones. However, they are most often used in supercharged, turbocharged and natural gas fueled engines due to the increased amount of heat generated by the said configurations. Engines of greater thermal loads use drilled valves filled with sodium, particularly the exhaust ones. Liquid molten sodium allows a heat transfer from the valve head to its stem during the valve motion. The valve transfers up to 25 percent more heat through its stem as compared to the one having an undrilled stem. This allows the valve head to operate under heavier heat load [2].

Empty drilled valves are approximately 10\% lighter than those filled with sodium [3].

Mahle Ventiltrib has developed a drilled valve, filled with sodium, made of N06601 alloy containing $60 \% \mathrm{Ni}$, which is $30-50 \%$ lighter than a conventional valve. It can operate in temperatures up to $1230 \mathrm{~K}$. The valve components have been made of steel of the thickness of $0.8-1.8 \mathrm{~mm}$ and welded by laser [4].

Drilled valves can also be made of titanium alloys [3]. Drilled steel valves have chrome-plated stems and seats with a hardness of 42 HRC [3]. szybciej, wymieniać większą ilość ładunku i mieć większą moc efektywną. Często są wykorzystywane zawory o zmniejszonej średnicy trzonków, co owocuje zmniejszeniem ich masy o 8-10 \% w porównaniu do standardowych zaworów [1]. Stosując lżejsze zawory uzyskuje się mniejsze naprężenia w sprężynach, miseczkach, dźwigienkach, popychaczach i krzywkach rozrządu. Zmniejszenie masy zaworów dolotowych jest efektywniejsze niż wylotowych, pod kątem uzyskiwania większych prędkości silnika. Posiadając, bowiem większe średnice grzybków, zawory dolotowe są cięższe od wylotowych. Dalsze zmniejszenie masy zaworów można osiągnąć przez zastosowanie drążenia zaworów lub/i lekkich materiałów. Zastosowanie lekkich zaworów umożliwia wykorzystywanie słabszych sprężyn o mniejszej masie. Iloczyn ujemnego przyspieszenia oraz masy zaworu $\mathrm{i}$ części masy sprężyny umożliwia oszacowanie siły sprężyny. Zmniejszenie masy zaworu o 40 \% umożliwia zmniejszenie sztywności sprężyn o około $30 \%$ [1].

Lekkie zawory mogą występować, jako stalowe drążone, ze stopów TiAl lub jako ceramiczne.

\section{Zawory drążone}

Jednym ze sposobów zmniejszenia masy zaworów jest stosowanie konstrukcji drążonej. W tych rozwiązaniach trzonki zaworów są drążone i mikropolerowane. Takie drążenie jest wykonywane w 2/3 górnej części trzonka, gdzie sztywność jest o rząd mniejsza niż w obszarze tuż nad grzybkiem zaworu. Po przewierceniu, na górze trzonka jest wspawana utwardzona końcówka. W rezultacie, uzyskuje się zawór o $20 \%$ lżejszy, niż w przypadku z pełnym trzonkiem. Zastosowanie drążonych zaworów w miejsce pełnych umożliwia zwiększenia zakresu prędkości silnika o 300-350 obr/min, bez konieczności modyfikowania rozrządu [2].

Mikropolerowanie zmniejsza ryzyko występowania karbów na wewnętrznej powierzchni trzonka [3].

Wiercenie powoduje zmniejszenie wytrzymałości, dlatego na zawory powinny być stosowane nieco mocniejsze stopy. Trwałość zaworów drążonych, stosowanych w silnikach wolnossących nie jest pogorszona w stosunku do trwałości zaworów pełnych. Nie są one jednak stosowane w silnikach doładowanych, turbodoładowanych i zasilanych gazem ziemnym, z powodu zwiększonej ilości generowanego w tych silnikach ciepła. W bardziej obciążonych cieplnie silnikach są stosowane drążone zawory, wypełnione sodem, zwłaszcza, jako wylotowe. Ciekły stopiony sód umożliwia w czasie ruchu zaworu przenoszenie ciepła z grzybka zaworu do jego trzonka. Taki zawór przenosi o 25 procent więcej ciepła przez trzonek niż zawór z pełnym trzonkiem. Umożliwia to pracę zaworu przy większych obciążeniach cieplnych grzybka zaworu [2].

Puste zawory drążone są około 10\% lżejsze niż wypełnione sodem [3].

Firma Mahle Ventiltrib opracowała drążony zawór, wypełniany sodem, wykonany ze stopu N06601 zawierającego $60 \%$ Ni, lżejszy o 30-50 \% od zaworów konwencjonalnych. Może on pracować w temperaturze do $1230 \mathrm{~K}$. Komponenty zaworu wykonane $\mathrm{z}$ blachy o grubości $0,8-1,8 \mathrm{~mm}$, były spawane laserowo [4]. 
Drilled titanium valves are available with drilled stems only or as a combination of drilled stems and heads. The use of drilled-stem valves only reduces the valve weight by approximately 10 per cent and a drilling of the valve head provides an additional $0.6-0.8 \mathrm{~g}$ reduction depending on the valve size. The inner part of the valve head can be strengthened by ribs to ensure adequate strength and stiffness [5].

\section{Valves made of TiAl alloys}

Currently, there are several methods in the production of titanium valves. One of them is powder metallurgy. Powder metallurgy allows a production of titanium rods for hot forging. Titanium exhaust valves are also made by casting and rolling of the $\mathrm{Ti}_{6} \mathrm{Al}_{2} \mathrm{Sn}_{4} \mathrm{Zr}_{2} \mathrm{MoSi}$ alloy. To increase the wear resistance of these valves the plasma carburizing is used [6].

Many titanium valves are produced by the initial forging and machining until the final shape is obtained. Some design forms are made as two partially treated segments joined together by friction welding, and then machined until the final shape is obtained [5].

To obtain a hard cup on the valve stem three methods are currently used: hardened steel cap, cap with a ceramic coating, thin film coating by the PVD technology [5].

Since titanium is relatively soft, hardened caps are usually used. For the valve stem diameters lower than $7 \mathrm{~mm}$ hard coated stems are used in order to avoid friction between the cap and the tip of the valve stem [5].

In the case of titanium valves with a Stellite friction-welded end it can be planned only to the $0.015-0.020 \mathrm{~mm}$ [5].

\section{Ceramic valves}

When ceramic valves are used instead of steel ones the valve weight reduction reaches up to $56 \%$ and the reduction of the valve spring load up to $20 \%$ [6].

Ceramic silicon nitride valves have been extensively investigated for applications in both light and heavy-duty engines. In light duty engines we can see an improvement in the fuel economy, the reduction of emissions and engine noise. In heavy-duty engines, a serious problem is durability and reliability due to a much longer service time and greater power outputs in comparison to light duty engines. Ceramic valves are made of brittle material that may fail due to a defect. Therefore, durability of ceramic valves cannot be accurately predicted using a theory based on limited statistical research of material properties. To evaluate the durability a non-destructive identification methods can be used (NDE) [7].

The region of the greatest load of the valve is in its thin subsurface layer. In this region, internal defects may occur such as porosity and voids and external damage remaining after mechanical treatment [8]. Ceramic valves can be diamond grinded [8].

\section{Computational model}

The schematics of a valve mating with the seat insert and the guide, with marked surfaces of heat transfer has been shown in Fig. 1.
Zawory drążone mogą być także wykonywane ze stopów tytanu [3]. Stalowe drążone zawory mają chromowane trzonki i przylgnie o twardości do 42 HRC [3].

Drążone zawory tytanowe są dostępne, albo jedynie $\mathrm{z}$ drążonymi trzonkami albo będące kombinacją drążonych trzonków i grzybków. Zastosowanie jedynie pustych trzonków zmniejsza masę zaworu o około $10 \%$, a wydrążenie grzybków o dodatkowe 3-5 \%, w zależności od wielkości zaworu. Wnętrze grzybka zaworu może zostać wzmocnione, na przykład żebrami, dla zapewnienia odpowiedniej wytrzymałości i sztywności [5].

\section{Zawory ze stopów TiAl}

Obecnie stosowanych jest kilka metod wykonania zaworów tytanowych. Jedną z nich jest metalurgia proszków. Metalurgia proszków pozwala produkować tytanowe pręty do kucia na gorąco. Inne tytanowe zawory wylotowe powstają poprzez odlewanie i walcowanie stopu $\mathrm{Ti}_{6} \mathrm{Al}_{2} \mathrm{Sn}_{4} \mathrm{Zr}_{2} \mathrm{MoSi}$. Dla zwiększenia odporności na zużywanie tych zaworów, stosuje się ich plazmowe nawęglanie [6].

Wiele zaworów tytanowych jest wytwarzanych poprzez początkowe kucie, a następnie obróbkę skrawaniem na ostateczny kształt. Niektóre konstrukcje są wykonywane, jako dwa częściowo obrobione segmenty, łączone ze sobą poprzez spawanie tarciowe, a następnie obrabiane skrawaniem na ostateczny kształt [5].

Dla zapewnienia twardych końcówek trzonków zaworu wykorzystywane są obecnie trzy sposoby: nasadki ze stali hartowanej, nasadki z pokryciem ceramicznym, cienkowarstwowe pokrycie technologią PVD [5].

Ponieważ tytan jest stosunkowo miękki, wykorzystuje się zazwyczaj utwardzone nasadki. Dla średnic trzonków zaworów mniejszych niż $7 \mathrm{~mm}$, jest wykorzystywane twarde powlekanie końcówki trzonka, dla uniknięcia oddziaływań tarciowych w styku nasadka-końcówka trzonka zaworu [5].

W przypadku zaworów tytanowych z przyspawaną tarciowo końcówką Stellite, może być ona szlifowana podczas naprawy, ale maksymalnie do 0,015-0,020 mm [5].

\section{Zawory ceramiczne}

W przypadku zastosowania zaworów ceramicznych występuje zredukowanie masy o $56 \%$ w stosunku do zaworów stalowych oraz zmniejszenie obciążenia sprężyn zaworów do 20 \% [6].

Ceramiczne zawory z azotku krzemu były intensywnie badane zarówno do zastosowań w lekko i wysokoobciążonych silnikach samochodowych. W lekko obciążonych silnikach występowało zmniejszenie zużycia paliwa, zmniejszenie emisji toksycznych składników spalin i hałasu silnika. W silnikach wysoko obciążonych poważnym problemem jest trwałość i niezawodność, z uwagi na znacznie dłuższy czas eksploatacji i większe moce, w porównaniu do silników lekko obciążonych. Zawory ceramiczne są wykonane z kruchego materiału, który może ulec uszkodzeniu z powodu jednej skazy. Dlatego trwałości ceramicznych zaworów nie można dokładnie przewidzieć, korzystając z teorii, opartych na ograniczonych danych statystycznych własności materiałowych. Do oceny trwałości można wykorzystać nieinwazyjne metody identyfikacyjne (NDE) [7]. 


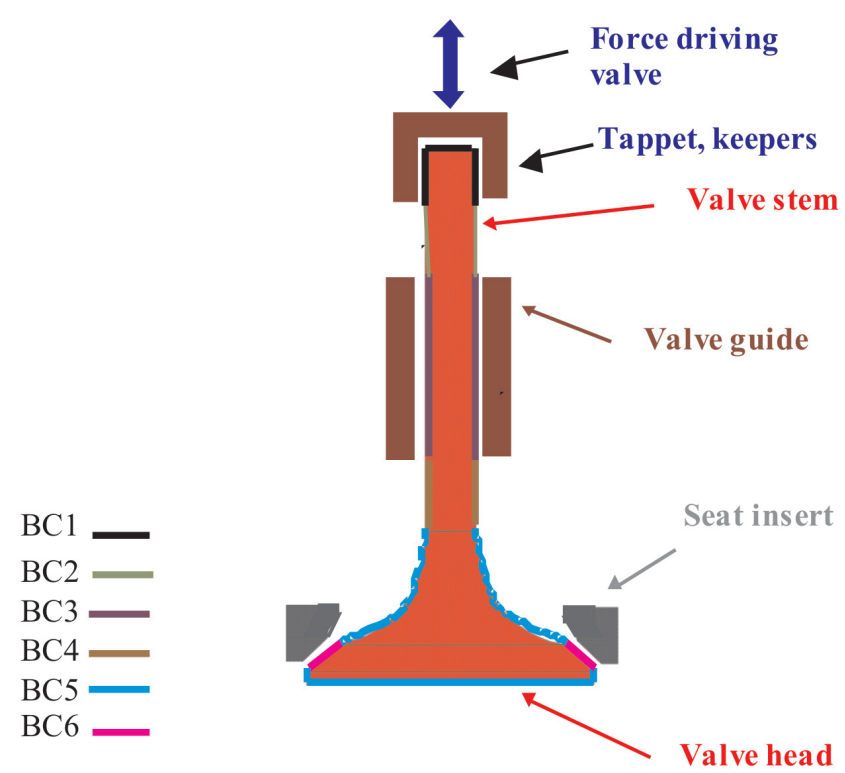

Power $\mathrm{Q}$ of transferred heat has been calculated from equation [1]

$$
\begin{aligned}
\mathrm{Q} & =\left[\tau^{-1} \int_{0}^{\tau} \alpha(\mathrm{t}) \mathrm{dt}\right] \mathrm{A}_{\mathrm{f}} \\
& \left(\left(\int_{0}^{\tau} \alpha(\mathrm{t}) \mathrm{dt}\right)^{-1} \int_{0}^{\tau} \alpha(\mathrm{t}) \mathrm{T}_{\mathrm{FLUID}}(\mathrm{t}) \mathrm{dt}-\mathrm{T}_{\text {WALL }}\right)
\end{aligned}
$$

Fig. 1. Schematics of a valve with its seat insert and its guide; $\mathrm{BC} 1$ - the surfaces of heat transfer by conduction: between the tappet and the tip surface of the valve stem and between the keepers and the stem, $\mathrm{BC} 2$ - the surface of heat transfer by convection between the stem and the surrounding fluid, BC3 - the surface of heat transfer: partly by convection between the stem and the fluid in the gap between the stem and the guide and partly by conduction between the stem and the guide, $\mathrm{BC} 4$ - the surface of heat transfer by convection between the valve and the surrounding fluid, BC5 - the surfaces of heat transfer by convection between the valve and the surrounding fluid, $\mathrm{BC} 6$ - the surface of heat transfer periodically: by conduction between the seats of the valve head and of the seat insert and by convection between the valve seat and the surrounding fluid

Rys. 1. Schemat napedzanego zaworu z gniazdem i prowadnica: $B C 1$ powierzchnie wymiany ciepła przez przewodzenie: między popychaczem i czolowa powierzchnia trzonka zaworu oraz miedzy klinami i trzonkiem zaworu, BC2 - powierzchnia wymiany ciepła przez konwekcję miedzy trzonkiem zaworu i otaczajacym plynem, BC3 - powierzchnia wymiany ciepta: częściowo przez konwekcję między trzonkiem zaworu i plynem w szczelinie miẹdzy trzonkiem zaworu i prowadnica oraz czéściowo przez przewodzenie między trzonkiem i prowadnica, BC4 - powierzchnie wymiany ciepla przez konwekcję między zaworem i otaczajacym plynem, BC5-powierzchnie wymiany ciepla przez konwekcje między zaworem i otaczajacym plynem, BC6 - powierzchnia wymiany ciepła między przylgniami zaworu i gniazda okresowo przez przewodzenie i okresowo przez konwekcję między przylgnia zaworu i otaczajacym płynem

Rejon największego obciążenia zaworu znajduje się w cienkiej warstwie podpowierzchniowej. W tym rejonie moga występować wewnętrzne wady, takie jak porowatość i puste przestrzenie, oraz zewnętrzne uszkodzenia poobróbkowe [8]. Zawory ceramiczne można szlifować diamentem [8].

\section{Model obliczeniowy}

Na rys. 1 pokazano schemat zaworu współpracującego z gniazdem i prowadnicą; z zaznaczonymi powierzchniami wymiany ciepła.

Table 1. The values of the heat transfer coefficient, partly based on [9]

\begin{tabular}{|c|c|c|c|}
\hline & \multirow{2}{*}{$\begin{array}{l}\text { Boundary conditions/ } \\
\text { warunki brzegowe }\end{array}$} & \multicolumn{2}{|c|}{ Time period/ okres } \\
\hline & & $\begin{array}{l}0-0.019 \text { s (contact valve-seat } \\
\text { insert/ styk zawór - gniazdo) }\end{array}$ & $\begin{array}{l}0.019-0.0 .29 \mathrm{~s} \text { (separation valve }- \text { seat } \\
\text { insert/ rozdzielenie zawór - gniazdo) }\end{array}$ \\
\hline \multirow[t]{2}{*}{$\mathrm{BC} 1$} & $\begin{array}{l}\text { Ambient temperature/ } \\
\text { temperatura otoczenia }[\mathrm{K}]\end{array}$ & 403 & 403 \\
\hline & $\mathrm{A}\left[\mathrm{W} / \mathrm{m}^{2} \mathrm{~K}\right]$ & 1500 & 1500 \\
\hline \multirow[t]{2}{*}{$\mathrm{BC} 2$} & $\begin{array}{l}\text { Ambient temperature/ } \\
\text { temperatura otoczenia }[\mathrm{K}]\end{array}$ & Linear gradient $403-473$ & Linear gradient $403-473$ \\
\hline & $\mathrm{A}\left[\mathrm{W} / \mathrm{m}^{2} \mathrm{~K}\right]$ & Gradient & Gradient \\
\hline \multirow[t]{2}{*}{$\mathrm{BC} 3$} & $\begin{array}{c}\text { Ambient temperature/ } \\
\text { temperatura otoczenia }[\mathrm{K}]\end{array}$ & 473 & 473 \\
\hline & $\mathrm{A}\left[\mathrm{W} / \mathrm{m}^{2} \mathrm{~K}\right]$ & 1000 & 1000 \\
\hline \multirow[t]{2}{*}{$\mathrm{BC} 4$} & $\begin{array}{l}\text { Ambient temperature/ } \\
\text { temperatura otoczenia }[\mathrm{K}]\end{array}$ & Linear gradient $473-573$ & Linear gradient $473-573$ \\
\hline & $\mathrm{A}\left[\mathrm{W} / \mathrm{m}^{2} \mathrm{~K}\right]$ & Gradient & Gradient \\
\hline \multirow[t]{2}{*}{ BC5 [9] } & $\begin{array}{l}\text { Ambient temperature/ } \\
\text { temperatura otoczenia }[\mathrm{K}]\end{array}$ & 573 & 873 \\
\hline & $\mathrm{A}\left[\mathrm{W} / \mathrm{m}^{2} \mathrm{~K}\right]$ & 250 & 400 \\
\hline \multirow[t]{2}{*}{ BC6 [9] } & $\begin{array}{l}\text { Ambient temperature/ } \\
\text { temperatura otoczenia }[\mathrm{K}]\end{array}$ & 573 & 873 \\
\hline & $\mathrm{A}\left[\mathrm{W} / \mathrm{m}^{2} \mathrm{~K}\right]$ & 15000 & 400 \\
\hline
\end{tabular}

Tabela 1. Wartości wspótczynników przejmowania ciepla, częściowo w oparciu o [9] 
where: $\mathrm{A}_{\mathrm{f}}-$ heat transfer area $\left[\mathrm{m}^{2}\right], \tau-$ time $[\mathrm{s}], \mathrm{T}_{\text {FLUID }}-$ the temperature of the surrounding fluid $[\mathrm{K}], \mathrm{T}_{\mathrm{WALL}}-$ the wall temperature $[\mathrm{K}]$.

Table 1 shows the values of the coefficients of heat transfer.

Table 2. The material parameters used in the model valve [12]

Tabela 2. Parametry materiałowe stref wykorzystanych $w$ modelu zaworu [12]

\begin{tabular}{|c|c|c|c|}
\hline $\begin{array}{c}\text { Material/ } \\
\text { materiat }\end{array}$ & $\begin{array}{c}\text { Density/ } \\
\text { gęstość }\end{array}$ & $\begin{array}{c}\text { Specific heat/ } \\
\text { ciepło wtaściwe }\end{array}$ & $\begin{array}{c}\text { Thermal } \\
\text { conductivity/ } \\
\text { przewodność } \\
\text { cieplna }\end{array}$ \\
\hline Steel & 7800 & 460 & {$\left[\mathrm{~W} / \mathrm{m}^{2} \mathrm{~K}\right]$} \\
\hline TiAl & 4500 & 523 & 58 \\
\hline Si3N4 & 3200 & 650 & 22.4 \\
\hline Air & 1.1 & 1005 & 0.025 \\
\hline
\end{tabular}

Values for coefficient of heat transfer $\alpha$ from the walls of the valve in the transition zones $\mathrm{BC} 2$ and $\mathrm{BC} 4$ have been calculated from equation [10]:

$$
\alpha=127.93 \cdot \mathrm{D}^{-0.2} \cdot \mathrm{p}^{0.8} \cdot \mathrm{w}^{0.8} \cdot \mathrm{T}_{\mathrm{FLUID}}^{-0.53}
$$

where: $\mathrm{D}$ - characteristic diameter $[\mathrm{m}], \mathrm{p}$ - the pressure of the surrounding fluid [bar], $\mathrm{w}-$ mean velocity of the valve $[\mathrm{m} / \mathrm{s}], \mathrm{T}_{\text {FLUID }}$ - temperature of the surrounding fluid.

The finite element mesh and the boundary conditions have been shown in Fig. 2. Computations have been made in the axisymmetric model. The finite element PLANE55 [11] of four nodes has been used in the model and its degrees of freedom have been nodal values of the temperature. The finite element mesh has been generated by a commercial computer program ANSYS [11]. As the boundary conditions the values of the heat transfer coefficient have been introduced to the outer surface of the

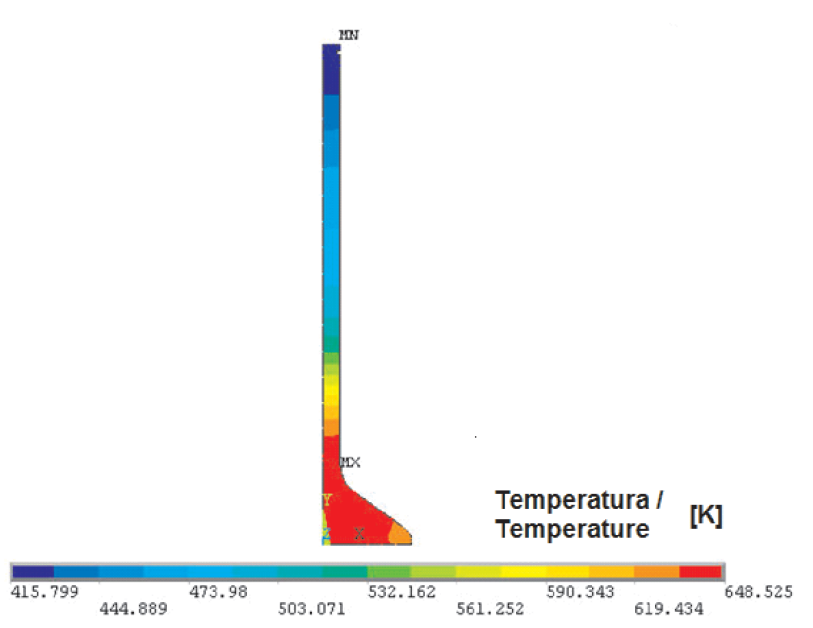

Fig. 3. The temperature distribution in a full valve made of steel Rys. 3. Rozklad temperatury w petnym zaworze stalowym

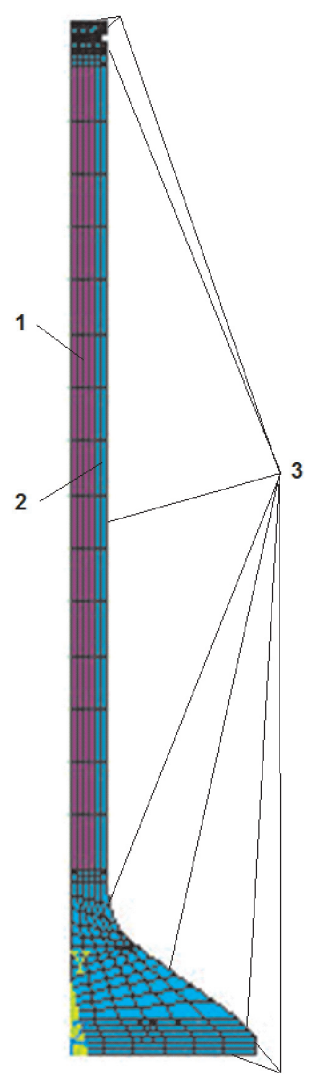

Fig. 2. The finite element mesh and the boundary conditions in the model of the lightweight valve; 1 - air, 2 - valve material, 3 - heat transfer coefficients on the surfaces of the valve depending on the temperature of the surrounding fluid (according to Table 1)

Rys. 2. Siatka elementów skończonych $i$ warunki brzegowe w modelu lekkiego zaworu; 1 -powietrze, 2 -materiał zaworu, 3-wspótczynniki przejmowania ciepła na powierzchniach zaworu w zależności od temperatury otaczajacego plynu (zgodnie z tabela 1)

Moc Q przejmowanego ciepła obliczano z wzoru (1) [1], gdzie: $A_{f}-$ powierzchnia wymiany ciepła $\left[\mathrm{m}^{2}\right], \tau-\operatorname{czas}[\mathrm{s}]$,

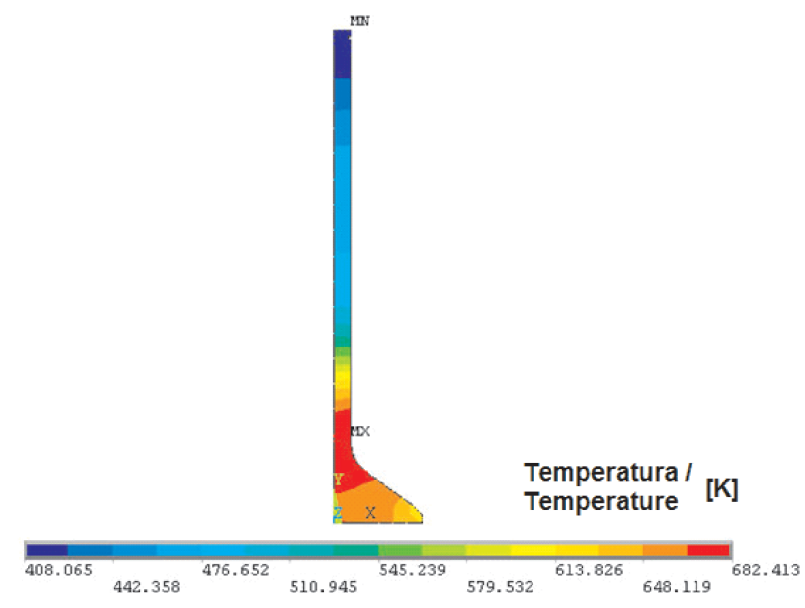

Fig. 4. The temperature distribution in a full valve made of the TiAl alloy

Rys. 4. Rozklad temperatury w petnym zaworze ze stopu TiAl 


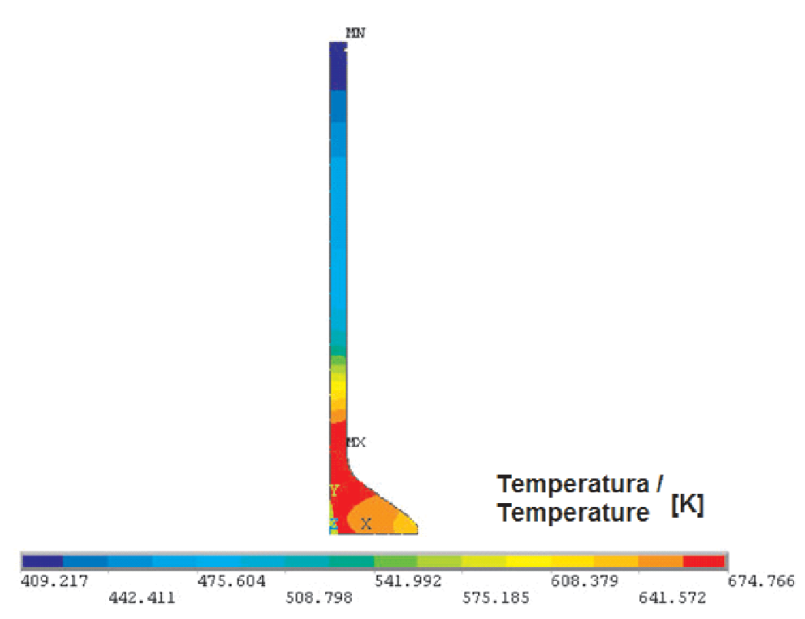

Fig. 5. The temperature distribution in a full valve made of $\mathrm{Si}_{3} \mathrm{~N}_{4}$ Rys. 5. Rozktad temperatury w petnym zaworze z $\mathrm{Si}_{3} \mathrm{~N}_{4}$

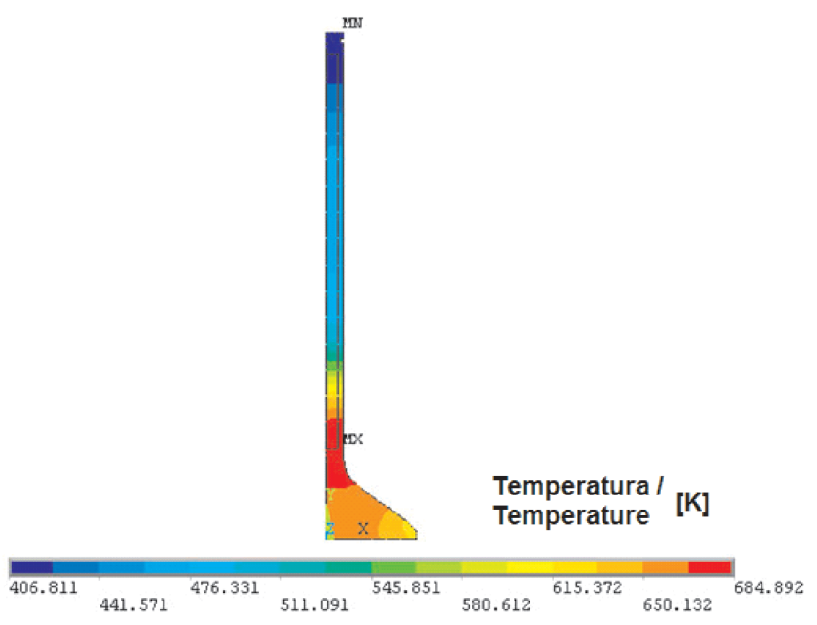

Fig. 7. The temperature distribution in a drilled valve with the bore diameter of $4 \mathrm{~mm}$

Rys. 7. Rozkład temperatury w zaworze drązonym o średnicy $4 \mathrm{~mm}$

valve. The values have been calculated for the temperature of the surrounding fluid, as shown in Table 1.

The material parameters used in the model have been shown in Table 2.

\section{The results of the research}

The calculated values of the temperature distribution in a full valve have been shown in Figure 3 - for a valve made of steel, Figure 4 - for a valve made of the TiAl alloy and Figure 5 - for a valve made of $\mathrm{Si}_{3} \mathrm{~N}_{4}$. The highest values of temperature were obtained for valves made of the TiAl alloy. They are $5 \%$ lower than in the case of a steel valve. The values of temperature obtained for the valve made of $\mathrm{Si}_{3} \mathrm{~N}_{4}$ are greater by only $4 \%$ than in the case of the steel one.

Figures 6 and 7 show the calculated temperature distribution for a drilled valve made of $\mathrm{Si}_{3} \mathrm{~N}_{4}$ with a bore of the diameter of 2 and $4 \mathrm{~mm}$ respectively. Increasing the bore diameter resulted in a non-linear increase of the values for the valve temperature. Such an increase was not great - of the order of $1.5 \%$ times the temperature values obtained for the full valve.

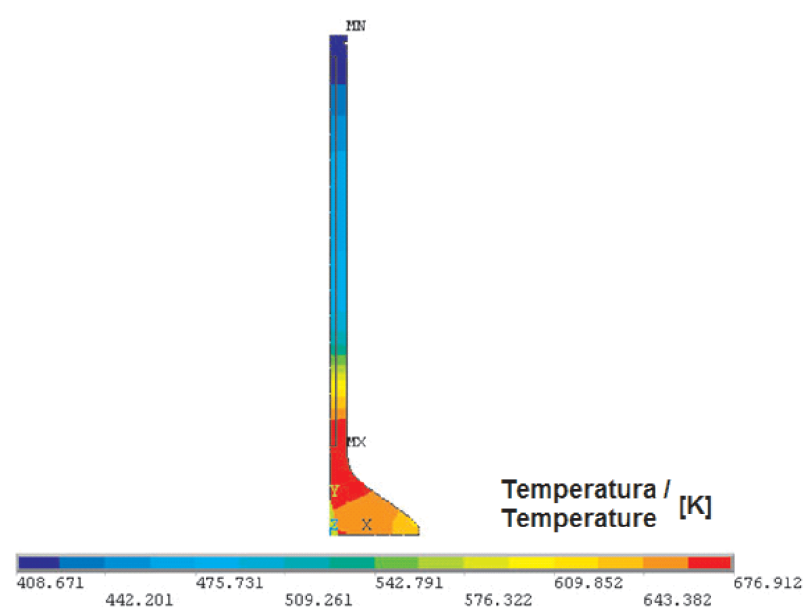

Fig. 6. The temperature distribution in a drilled valve with the bore diameter of $2 \mathrm{~mm}$

Rys. 6. Rozklad temperatury w zaworze drążonym o średnicy otworu $2 \mathrm{~mm}$

$\mathrm{T}_{\mathrm{FLUID}}-$ temperatura otaczającego płynu $[\mathrm{K}], \mathrm{T}_{\mathrm{WALL}}-$ temperatura ścianki $[\mathrm{K}]$.

W tabeli 1 podano wartości współczynników przejmowania ciepła.

Wartości współczynników $\alpha$ przejmowania ciepła od ścianek zaworu w strefach przejściowych BC2 i BC4 obliczano ze wzoru (2) [10],

gdzie: D - średnica charakterystyczna [m], p - ciśnienie otaczającego płynu [bar], w - średnia prędkość zaworu $[\mathrm{m} / \mathrm{s}]$, $\mathrm{T}_{\text {FLUID }}$ - temperatura otaczającego płynu.

Siatkę elementów skończonych i warunki brzegowe pokazano na rysunku 2. Obliczenia wykonano w modelu osiowosymetrycznym. Do modelowania użyto czterowęzłowego elementu skończonego PLANE55 [11], którego stopniami swobody były węzłowe wartości temperatury. Siatka elementów skończonych została wygenerowana przez komercyjny program obliczeniowy ANSYS [11]. Jako warunki brzegowe wprowadzono współczynniki przejmowania ciepła z powierzchni zewnętrznej zaworu obliczane dla temperatury otaczającego płynu, zgodnie z tabelą 1 .

Parametry materiałowe użyte $\mathrm{w}$ modelu przedstawiono w tabeli 2.

\section{Wyniki badań}

Obliczony rozkład wartości temperatury w pełnym zaworze pokazano na rysunku 3 - dla zaworu stalowego, na rysunku 4 - dla wykonanego ze stopu TiAl oraz na rysunku 5 - dla wykonanego $\mathrm{z} \mathrm{Si}_{3} \mathrm{~N}_{4}$. Największe wartości temperatury uzyskano dla zaworu wykonanego ze stopu TiAl. Były one o $5 \%$ większe niż w przypadku zaworu stalowego. Wartości uzyskane dla zaworu z $\mathrm{Si}_{3} \mathrm{~N}_{4}$ były większe tylko o $4 \%$ niż w przypadku zaworu stalowego.

Na rysunkach 6 i 7 pokazano obliczone rozkłady temperatury dla drążonego zaworu z Si3N4, o średnicy otworu 2 i $4 \mathrm{~mm}$. Zwiększenie średnicy otworu powoduje nieliniowy wzrost wartości temperatury zaworu. Wzrost ten nie jest duży, rzędu $1,5 \%$ wartości temperatury uzyskanych dla zaworu pełnego. 


\section{Summary}

The calculated values of temperature distribution in the case of full lightweight valves are only a few percent greater than in the case of steel valves with the same geometry and subjected to the same thermal load. Valve drilling causes only a slight increase in the valve temperature values as compared to a full valve.

\section{Podsumowanie}

Obliczone wartości temperatury w lekkich pełnych zaworach są tylko o kilka procent większe, niż w zaworze stalowym o takiej samej geometrii i poddanego takim samym wymuszeniom cieplnym. Drążenie zaworów powoduje jedynie niewielki wzrost wartości temperatury w zaworze, w porównaniu z zaworem pełnym.

\section{Nomenclature/Skróty i oznaczenia}

BC1, .., BC6 heat transfer zone (boundary conditions)/strefa wymiany ciepta (warunki brzegowe)

power of transfered heat/moc wymienianego ciepta

$\mathrm{A}_{\mathrm{f}} \quad$ area of transferred heat/powierzchnia wymiany ciepła

$\tau \quad$ time/czas

$\alpha \quad$ heat transfer coefficient/współczynnik przejmowania ciepta
$\mathrm{T}_{\text {FLUID }}$ temperature of the surrounding fluid/temperatura otaczającego ptynu

$\mathrm{T}_{\text {WALL }}$ temperature of the wall/temperatura ścianki

D characteristic diameter/średnica charakterystyczna

$\mathrm{p} \quad$ pressure of the surrounding fluid/ciśnienie otaczajacego ptynu

w mean valve velocity/średnia prędkość zaworu

\section{Bibliography/Literatura}

[1] Siczek K: Badania i modelowanie zjawisk tribologicznych zachodzących w układzie prowadnica - lekki zawór - gniazdo w rozrządach silników spalinowych, rozprawa habilitacyjna, Politechnika Łódzka, Łodź, 2012 (in Polish).

[2] Kaufman D.: Engine Builder Magazine, 11/25/2008, http:// www.underhoodservice.com/Article/40385/tech_feature_understanding_valve_design_and_alloys.aspx.

[3] http://www.precisionenginetech.com/tech-explained/2009/06/02/ valve-materials-and-designs-part-2/

Krzysztof Siczek, DEng. - doctor in the Faculty of Mechanical Engineering at Technical University of Lodz.

Dr inż. Krzysztof Siczek - adiunkt na Wydziale Mechanicznym Politechniki Lódzkiej.

e-mail: krzysztof.siczek@p.lodz.pl
[4] Abele M.: A lightweight valve made from a nickel alloy, Nickel magazine, March, 2004 , http://www.nickelinstitute.org/index. cfm/ci_id/12774/la_id/1/document/1/re_id/0.

[5] http://www.precisionenginetech.com/tech-explained/2009/06/02/ valve-materials-and-designs-part-1/

[6] Hiroshi Yamagata: The science and technology of materials in automotive engines, Woodhead Publishing Ltd, Cambridge England 2005.

[7] http://www.sbintl.com/valveseatinserts.html

[8] Sun J.G., Zhang J.M., Andrews M.J., Trethewey J.S., Philips N.S.L., Jensen J.A.: Evaluation of Silicon-Nitride Ceramic Valves, International Journal of Applied Ceramic Technology, 5 (2), 2008, pp. 164-180.

[9] Wiśniewski T.S., Banaszek J., Furmański P., Rebow M.: Influence of boundary conditions on temperature distribution in valve seat of IC engine by FEM analysis, Journal of KONES, Bielsko - Biała, 1997, pp. 463-468.

[10] Merker G.P., Schwarz C., Stiesch G., Otto F.: Simulation Combustion. Simulation of combustion and pollutant formation for engine-development, Springer, Berlin, 2006.

[11] ANSYS help documentation

[12] pl.wikipedia.org 